Anita Srebnik

Universiteit van Ljubljana

https://doi.org/10.18485/bgd_nlistiek_30.2018.ch6

\title{
UNIVERSALISME EN TOLERANTIE BIJ SLAVOJ ŽIŽEK EN STEFAN HERTMANS
}

Er zijn geen Joden of Grieken meer, slaven of vrijen, mannen of vrouwen - $u$ bent allen één in Christus Jezus. (Galaten, 3: 28)

\section{Abstract}

In this paper I will try discuss the issues of tolerance and the accompanying notions like universalism (paulinism), globalisation and engagement (participation) from the perspective of the Flemish writer Stefan Hertmans and the Slovene philosopher Slavoj Žižek whose work Hertmans is very well acquainted with. Parallels can be drawn as to the Christian universalism which is anything but universal through its exclusion of the Other from its system (Hertmans) and its formulation from the position of the excluded which in turn universalises the difference Christians/non-Christians (Žižek).Since Paulus there is a strong tendency towards homogenisation (egalisation) up to this day which is noticeable throughout our social system. For both thinkers universalism is a problem of global capitalism whose driving force reveals itself in multiculturalism as its ideal form of ideology. In all fields of the society (politics, economy, culture) there is evidence of the same balance of power (inactive left and mobilised right) as a consequence of the depolitisation of politics and economy. The multiculturalist discourse today is problematic because of the misjudged position of the subject. The intolerance toward the Other is a frequent occurrence and the way out is not just being tolerant toward the Other and keeping the appropriate distance. At the same time one should attempt an emancipatory struggle, which is deeply rooted already in the early Christian teachings, i.e. rise above its particular identity - to be able to find the universality of humanity.

Keywords: philosophy, universalism, multiculturalism, tolerance

\section{Inleiding}

Het is niet toevallig dat mijn keuze voor de invalshoek van de gedachtewisseling over (in)tolerantie viel op filosofie en beschouwend proza. Beide graven dieper onder de verschijningsvorm van de werkelijkheid in uiteenlopende richtingen en bedienen zich van sprongen of zelfs (meervoudige) 180-graden wendingen. De Sloveense filosoof, cultuurcriticus en psychoanalyticus Slavoj Žižek (1949) is daar ongetwijfeld een meester in. Diens cultuurkritische kijk op de vraag van tolerantie, universalisme 
en begrippen die ermee gepaard gaan, worden in deze bijdrage vergeleken met het gedachtegoed van de veelzijdige Vlaamse schrijver, dichter en essayist Stefan Hertmans (1951).Hertmans poëtica is sterk beïnvloed door filosofen (Plato, Hegel, Nietzsche, Kierkegaard, Levinas, Nussbaum, Lacan, Heidegger, Derrida, Badiou, Sloterdijk, Žižek en vele anderen). Hertmans ideeënwereld komt expliciet aan bod in veel van zijn essays en wordt getekend door enorme cultuurhistorische en filosofische eruditie, scherpe analysen, enthousiasme en empathie. Hij is een goede kenner van Slavoj Žižek, die hij een hype filosoof noemt, een denkbeest dat zich met een nog nooit geziene drift heeft gestort op een Lacaniaanse analyse van onze cultuur, een sputterende en gesticuleerende profeet van onze tijd. Maar de filosofen aan wie Žižek het meest schatplichtig is, zijn de Duitse idealisten, met name Hegel.

Van de filosofie zouden we vandaag de dag op zijn minst een oplossing verwachten voor talloze problemen en conflicten waarin onze samenleving verzeild is geraakt.Žižek, en hij is beslist niet de enige, beweert dat de taak van de filosofie niet in het geven van antwoorden ligt. De filosofie kan ons wel erop wijzen dat het hem in de manier zit waarop we een probleem beschouwen en dat onze waarneming het probleem vaak zelf smystificeert.

\section{Paulinisme als het universalisme}

Enkele dagen na de aanval op de WTC in New York gaf Žižek een interview voor de Left Business Observer. Hem werd o.a. gevraagd waarom hij het christelijke gedachtegoed verdedigt, waarop hij antwoordde: vanwege de verrijzenis en het universele karakter van de waarheid. Volgens Žižek neemt het christendom met de heilige Paulus een radicalere wending en dit zet aan tot een nieuw soort ethiek met toegang tot het universalisme voor iedereen, ongeacht wie hij is. ${ }^{1}$ Slavoj Žižek staat op dit moment samen met de Franse filosoof Alain Badiou en de Italiaanse filosoof Georgio Agamben in het centrum van de herwaardering van de erfenis van de heilige Paulus. ${ }^{2}$ Het zijn allemaal seculiere filosofen die weliswaar niet Paulus' geloof in verrijzenis delen maar die het wel beschouwen als de kern van het hedendaagse politieke leven en de

1 'Ik ben een strijdend atheïst. [...] Wat het christendom deed, in een religieus gemystificeerde versie, is ons een idee van de verrijzenis aan te reiken. Tegenover het heidense begrip van de lotsbeschikking. Het christendom bood de mogelijkheid tot een radicale opening, zodat we een niets kunnen vinden en helemaal opnieuw kunnen beginnen. Het bracht een nieuw soort ethiek binnen: niet dat je doet wat je moet doen omdat dat je plicht is vanuit je maatschappelijke positie - een goede koning hoort een goede koning te zijn, een goede knecht een goede knecht - maar dat ik ongeacht wie ik ben, een directe toegang tot het universalisme heb. Dit is explosief. Wat mij interesseert is alleen deze dimensie. Natuurlijk hebben dat later de seculiere filosofen overgenomen. Ik neem de kerk als institutie in geen enkel opzicht in bescherming, niet in het minst.'

2 Alain Badious boek Paulus: de fundering van het universalisme (Saint Paul: La fondation de l'universalisme, Paris 1997) is een van de eerste Badious boeken die Žižek van hem las. In dat boek ontwikkelt Badiou zijn ontologische waarheidstheorie en past die toe op het christendom. 
reflectie. Ze zien in het paulinisme het universalisme van de waarheid, 'de overtuiging dat datgene wat waar is voor iedereen waar is en dat de juiste rol van het subject het verspreiden van deze waarheid is, de strijd in de naam van deze waarheid (apostolos)' (De Caputo 2009: 2).

Niet alleen filosofen, historici of theologen buigen zich over de nalatenschap van de heilige Paulus. Ook Stefan Hertmans reflecteert op zijn werk en de langdurige implicaties ervan. Zijn essay Mogen allen worden als ik met als ondertitel Over de droom van het globalisme 3 begint Hertmansin het vroege christendom met de apostel Paulus, de felle en veel gevreesde verspreider van de Romeinse cultuur in de Palestijnse provincies. Hij was van betere stand en behoorde tot de overheersende cultuur, die voor beschaving en vooruitgang stond. Als zijn voornaamste taak zag hij de strijd voor haar eenheid en de bescherming tegen vreemde invloeden.

$\mathrm{Na}$ zijn wonderlijke bekering onderweg naar Damascus, als hij letterlijk verblind raakt en na enkele dagen weer geneest door de hulp van de vrome Ananias, is hij gereed om de nieuwe waarheid onder ogen te zien. Hij wordt een 'strijder voor de zaak die hij even tevoren heeft bevochten. Meer nog, hij wordt de fanatiekste incarnatie van zijn vroegere tegenstander' (Hertmans 2002:12). De nieuwe waarheid verdringt de vroegere, maar behoudt de oude structuur. De andere waarheid is onmogelijk omdat er slechts één waarheid, Paulus' waarheid kan bestaan. Maar de mensen twijfelen aan zijn ware bedoelingen en vragen zich af hoe het mogelijk is om van de ene op de andere dag zo'n radicale omslag te ondergaan. Paulus, echter behoudt zijn militante houding waarmee hij gisteren nog de christenen meedogenloos achtervolgde en liet terechtstellen en gaat onverstoorbaar door met de bekering van de anderen tot het christendom.

Toch is Paulus volgens Hertmans niet bekrompen, integendeel, hij is juist op een rare manier ruimdenkend omdat hij helemaal open staat voor het standpunt van de anderen, ook diegenen die hij zonet verachtte. In het besef dat de anderen gelijk kunnen hebben en zijn leven tot nu toe misschien verkeerd was, neemt hij de (christelijke) waarheid van de anderen over.

Paulus lijdt niet aan blindheid of aan regionalisme, hij lijdt aan de blikvernauwing van zijn universalisme [...] Hij staat open voor een zelfcorrectie, maar hij behoudt de houding die hij had: hij wil elke andere aan hemzelf gelijk maken. Hij wórdt het andere [...] Zodra Saulus/Paulus tot het 'andere' kamp behoort, wil hij zijn vroegere kompanen met evenveel felheid bestrijden; hij staat zijn eigen vroegere ik radicaal naar het leven. De obsessie is zo sterk, dat hij, die de christenen eerst aan de Romeinse wet wilde onderwerpen en zijn slachtoffers zo haatte dat hij ze figuurlijk gesproken ging interioriseren, ze als het ware ging opeten. Hij slikt de christelijke vijand integraal in... en wórdt hem. Deze incarnatie - letterlijk: de Ander vleselijk gaan belichamen - vormt het kannibalistisch oermodel van de eucharistie. (Hertmans 2002: 13-14)

3 Mogen allen worden als $i k$. Over de droom van het globalisme verscheen in het essaybundel Het putje van Milete (2002), Amsterdam: Meulenhoff. 
Hertmans merkt op dat vanaf dat moment het christendom radicaal verandert: wat tot nu toe de universele geest van de Romeinen was, wordt nu de universele boodschap van de bekering.

In het vervolg beschrijft Hertmans hoe de eerste christelijke gemeenschappen tot dan toe leefden: vrij bescheiden, ook al ijverig in hun geloof, zich concentrerend op het overleven in het gezicht van de dominante, Romeinse cultuur en niet bepaald van plan om alle Romeinen of Germanen te bekeren.Dat was de typische toenmalige godsdienstige houding in het Midden-Oosten: de mensen belijden hun geloof en leven in het besef dat de anderen het niet noodzakelijkerwijs met hen eens zijn. De Ander blijft gewoon de Ander. Ook de oorspronkelijke islam zou er in Hertmans' ogen niet per se op uit zijn om de hele wereld te overtuigen. Maar met de aanvallen van de kruisvaarders uit het westen verandert deze houding grondig. De eerste christenen waren dus nog geen predikers, missionarissen of brengers van de boodschap. Met Paulus komt het echter tot een omslag. Hij begeeft zich naar Rome om zijn boodschap daar verder te verspreiden. 'De universele gedachte van Paulus is een gedachte van de algemene gelijkheid; er zullen geen 'anderen' meer zijn, allen zullen 'gelijken' worden, en wel gelijken die alleen op hém lijken.' (ibid:16) Het gevolg van deze gedachte is een eentonige wereld waar geen plaats is voor de Ander behalve als hij als een mentaal spiegelbeeld van de eigen verwachtingen verschijnt, aldus Hertmans.

Žižek benadert Paulus in meerdere werken, o.a. ook in zijn filosofisch boek De parallactische kijk (The Parallax View, 2006). Paulus' woorden 'geen Joden of Grieken meer'haalt hij aan als uitgangspunt van zijn vertoog over Paulus' universalisme. Paulus was zich bewust van en was zelfs trots op zijn particuliere identiteit - hij was Jood en een Romeinse burger. De strijd voor de christelijke absolute waarheid, waarin hij met heel zijn hart en ziel verwikkeld is, is niet simpelweg universeler dan de strijd van de ene etnische groep tegen de andere. Volgens Žižek gaat het om een strijd met een volstrekt andere logica, dus niet om een strijd tussen verschillende identiteitsgroepen onderling maar om een antagonisme dat diagonaal door alle particuliere groepen heen snijdt (Žižek 2006:9). Voor deze constatering vindt hij al snel een tegenargument, namelijk dat we het ook over de eerste stap in de richting van 'de cartesiaanse multiculturele openstelling' kunnen hebben, een relativering van je eigen positie, het achter zich laten van traditionele meningen enz (ibidem).

De allesomvattende stelling van het christelijke universalisme die met Paulus' woorden 'geen Joden of Grieken meer' werd ingeleid - is in de ogen van Žižek gelijk aan een volstrekte uitsluiting van degenen die zich niet bij de christelijke gemeenschap willen aansluiten. In andere particuliere religies en zelfs in de islam, niettegenstaande zijn globale expansie, zou er plaatszijn voor de Ander. De Ander wordt getolereerd ook al kijkt men minachtend op hem neer.Het christelijke motto 'Alle mensen zijn broeders' betekent volgens Žižek ook 'Diegenen die niet mijn broeders zijn, zijn niet (eens) mensen'4. Zijn kritiek reikt nog verder: de christenen zouden zichzelf verheerlijken omdat ze het Joodse denkbeeld van het Uitverkoren Volk hebben overstegen waardoor ze nu de hele mensheid omsluiten. Het probleem is echter dat de Joden, juist omdat

4 Alle citaten uit niet-Nederlandse bronnen zijn in vertaling van de auteur van dit artikel. 
ze volharden in hun overtuiging van het Uitverkoren Volk en dus een geprivilegieerde band met God, de mensheid van de anderen die in valse goden geloven wel accepteren, terwijl het christelijke universalisme de niet-gelovigen uitsluit van de universele mensheid (ibid:35). Maar het christelijke universalisme is geen allesomvattend globaal medium waar plaats is voor iedereen, het is een gebied van voortdurende strijd. Om met Paulus te spreken gaat het niet om de scheiding tussen de Wet en de zonde, maar tussen de totaliteit van de Wet en de zonde aan de ene kant en de Liefde aan de andere. Het christelijke universalisme wordt zo een symptomatisch medium van degenen die 'deel van geen-deel' van de globale orde zijn, vindt Žižek (ibidem).

In het vervolg legt hij de fout bloot in de kritiek op het christelijk universalisme. Het gaat er allesbehalve om, dat het sommige subjecten uitsluit, want het is juist geformuleerd vanuit de positie van diegenen die uitgesloten zijn.Of met andere woorden: de beschuldiging van Paulus' universalisme mist de ware kant van het universalisme: de dimensie die hij openbaart betreft niet 'geen Joden of Grieken meer[...]allen één in Christus Jezus' waarvan impliciet niet-christenen uitgesloten zijn. Het betreft eerder het verschil christenen/niet-christenen zelf, dat als verschil universeel is. Dit verschil 'als het ware snijdt door het hele sociale lichaam heen, splitsend en scheidend vanuit iedere substantiële etnische enz. identiteit - Grieken zijn verdeeld in christenen en niet-christenen, evenals de Joden.' (ibidem) Daarom, concludeert Žižek, trapt men met de standaardbeschuldiging een open deur in, want feit is, dat het ware universalisme en particularisme elkaar niet uitsluiten, en dat de universele waarheidalleen toegankelijk is vanuit 'een partieel geëngageerde subjectieve positie' (ibid: 36).

Ook Hertmans' en Žižeks vertoog sluiten elkaar niet uit, zij het dat Žižek het paulinisme vooral vanuit de filosofische - Hegeliaans en Lacaans getinte - kant bekijkt en hij in dialoog staat met een aantal filosofen zoals Kant en Descartes, Badiou, Agamben, Sloterdijk, Laclau en nog veel meer. Het resultaat is een uiterst complex beeld van het christendom waaruit ik de belangrijkste premissen probeer aan te stippen die op het christelijk universalisme wijzen om zo Hertmans en Žižek bij elkaar te brengen.

Om met Hertmans terug te keren naar de geschiedenis van de paulinische leer in Griekenland, hij wijst ons eerst op de Griekse afkomst van het woord barbaar, i.e. barbaroi, in de betekenis van iedereen die geen Grieks kon spreken en slechts letterlijk 'barbarbar' kon brallen (Hertmans 2002:16). Evenals de eerste Christenen waren ook de Grieken niet van plan om de anderen te bekeren, 'de anderen misprijzen was hun ruimschoots voldoende [...] Universaliteit was een zaak van de filosofen, die zich over het lot van de mens bogen; universeel was de mentaliteit van de Griekse tragedie'(ibidem). Na hun bekering legden ze het tragische wereldbeeld af en vervingen hem door het drama van de retorische overtuiging, aldus Hertmans voor wie de westerse cultuur getekend is door dit drama van bipolariteiten. Toen gold dat de Ander 'een emanatie van de Antichrist' is en dat naast God alleen nog de Satan is. Je moest zogenaamd wel kiezen voor God, 'uit eigen vrije wil, maar er is geen ander artikel in de rekken te vinden' (ibid:17-18). 


\section{Universalisme en globalisme}

De machtigste egaliseringstendens door de geschiedenis heen ziet Hertmans na Paulus in de Verlichting die volgens hem eropuit is de Ander in zijn andersheid op te heffen want die moet op ons lijken. Tegelijkertijd geeft hij toe dat er voor de redelijkheid van de Verlichting ook geen ander alternatief bestaat, het schema van de Verlichting is zonder twijfel vervuld van alles wat ons dierbaar is, onze erfenis van het humanisme. Maar de Ander is van dit schema uitgesloten, want die moet op ons lijken, waar ook ter wereld.Met zijn constatering dat 'onze export van het universeel humanisme slechts het symptoom van ons terugverlangen [is] naar een spiegel waarin we onszelf kunnen aanwijzen', slaat hij de brug naar de hedendaagse ideologie van het globalisme, die zichzelf niet als ideologie wil zien (Hertmans 2002:19).

Het negentiende-eeuwse kolonialisme bracht miskenning van andere culturen mee: terwijl men ze geïnteresseerd observeerde als iets exotisch, geloofde men naïef in de mogelijkheid dat onze versie van universalisme daadwerkelijk universeel kon zijn (ibid: 18-27; Žižek 1998: 48-49). De westerse wereld draagt, zo betoogt Hertmans, zijn universalisme uit als een planetaire droom, maar het is slechts een regionale droom, de paulinische droom oftewel het internationalisme, want het grootste deel van de zeven miljard mensen gaat niet van dit westerse paulinische model uit. Hertmans en Žižek zijn het erover eens dat het universalisme het probleem van het mondiaal kapitalisme is. Of zoals Hertmans het treffend stelt:

Internationalisme is een laat-kapitalistisch product van het paulinisme, tot ijzer gesmeed in de scholen van Port Royal en de strenge jezuitische, klassiek georiënteerde tradities, van sofistische logica voorzien in de liberale theorieën omtrent individu en leefwereld, materieel geobjectiveerd in de aanmaak van technische innovaties die de schijn van een universele 'behandeling' van de wereld mechanisch moesten reproduceren, uitgegroeid tot een verschrikkelijk misverstand in de negentiende-eeuwse tragedies van de kolonialisering, ten slotte fijngeslepen in de praktijken van de psychoanalyse. Een groot deel van de brandhaarden die de afgelopen decennia in de niet-westerse wereld zijn ontstaan, werd aangestoken door de import van deze westerse idee: dat het onduldbaar is als de ander niet op ons lijkt. (ibid:20-21)

Žižeks opvatting van hoe het kapitalisme vroeger functioneerde en welke rol het nu vervult, komt kort gezegd op het volgende neer. Ideaal gesproken circuleerde het kapitaal aanvankelijk binnen de grenzen van de natiestaat en werd er internationale handel gedreven met andere natiestaten. Daarop volgde de koloniale fase waarbij de koloniale macht de kolonie economisch, politiek en cultureel uitbuitte. Maar in de laatste fase van de kolonisatie treedt de paradox op; er blijven alleen nog maar kolonies over en er zijn geen koloniale machten (als natiestaten) meer. De koloniale macht is nu eenmaal een multinational. En de drijfmotor van dit mondiaal kapitalisme is multiculturalisme. Multiculturalisme als zijn ideale vorm van ideologie, aldus Žižek (1998:48-49). Hij beschrijft de huidige relatie tussen de multinational en zijn 
kolonies als "zelf-kolonisatie«. Dat wil zeggen dat vanwege de multinationale functie van het kapitaal de gangbare tegenstelling tussen de metropool en de gekoloniseerde landen is opgeheven, de multinational knipt als het ware de navelstreng met zijn land van oorsprong door en behandelt het gewoon als een territorium dat moet worden gekoloniseerd. Dat leidt volgens Žižek tot ergernis bij rechtse populisten: het feit dat de nieuwe multinationals tegenover de Franse of Amerikaanse lokale bevolking dezelfde houding innemen als b.v. tegenover de bevolking van Mexico, Brazilië of Taiwan.

Belangrijk hier is Žižeks parallel tussen het traditionele imperialistische kolonialisme en de wereldomvattende kapitalistische zelf-kolonisatie aan de ene kant en precies dezelfde relatie tussen het westerse cultuurimperialisme en het multiculturalisme aan de andere kant. Zo krijgen we enerzijds het wereldkapitalisme met de inherente paradox van de kolonisatie zonder metropool in de natiestaat, en aan de andere kant het parallel lopende multiculturalisme zonder enige wortels in de eigen cultuur.

In zijn kritiek op het paulinisch schema dat zich voltrekt onder het mom van technologische innovaties en hun voor het welzijn van de mensen noodzakelijke export, haalt Hertmans Žižek aan die beweert dat multiculturalisme het perfecte glijmiddel is geworden voor het mondiaal kapitalisme - de ultieme kolonisatie (Hertmans 2002: 26). Hij bekrachtigt daarmee Žižeks betoog dat het multiculturalisme slechts de verschijningsvorm van zijn eigen tegendeel is: de uitbreiding van het kapitalisme over de hele wereld.

Hieruit blijkt wel hoe ongekend homogeen de moderne wereld geworden is. Het is net alsof, nu de horizon van de maatschappelijke verbeelding geen ruimte meer laat voor de gedachte dat het kapitalisme uiteindelijk zal sterven - omdat iedereen stilzwijgend accepteert dat het kapitalisme nooit meer weggaat - de kritische energie de alternatieve uitlaatklep heeft gevonden in de strijd om de culturele verschillen die de fundamentele homogeniteit van het wereldomvattende kapitalistische systeem niet aantasten. (Žižek $1998: 52$ )

\section{Het mondiale dorp en het multiculturalisme}

Žižeks boek Pleidooi voor intolerantie is een strikt theoretisch boek geschreven vanuit een grote affiniteit met Hegels dialectiek en Lacanse psychoanalyse. Volgens Hegels dialectiek is het gelijke gelijk in het verschil en deze logica hanteert ook Žižek. Omdat ze onderling verschillen kunnen we alle culturen vanuit een gelijk gezichtspunt benaderen. Juist omdat ze anders zijn, staan ze open voor de logica van de globale hegemonie oftewel de vrijemarkteconomie. Er zou een wederzijdse tolerantie bestaan voor elkaars verschillen, maar de in het bovenste citaat genoemde culturele verschillen zijn slechts een voorwendsel voor de werkelijke depolitisering van zowel economie als politiek. Geen wonder dat we onze wereldeen global villagezijn gaan noemen. Aan de ene kant zijn we allemaal gelijk aan elkaar (te veel tolerantie noemt Žižek dat), aan de 
andere kant, om met Hertmans te spreken, zijn in dit kosmisch dorp van de Nieuwe Orde alleen zij welkom, die zich conformeren aan de ideologie van de vrije markt. 'De dorpsmentaliteit is [...] het model van het universum geworden - en niet omgekeerd.' (Hertmans 2002:28) Te weinig tolerantie noemt Žižek dat.

Wie is dus de drager of het subject van dit mondiale dorp? Žižeks logica volgt ook hier strikt Hegels begrip van het subject ${ }^{5}$ en het is Žižeks inbreng dat hij het een gedecentreerde draai geeft. Daarom manifesteert dit dorp niet gewoon in de wereld zelf, maar in 'datgene waar het verschil mee maakt' (De Kesel 1999: 55). Juist in het verschil, uit naam van zijn symptoom, uit naam van het deel dat weliswaar inherent aan de bestaande universele orde is, maar hierin geen eigen plaats kent, geschiedt dit globale dorp (Žižek 1998:59). Žižek noemt als voorbeeld van dit inherente deel, als»deel van geen-deel«, de illegale buitenlanders. In zijn redenering schuilt Hegels subject logica, maar Žižek gaat nog een stap verder. Hij laat het subject niet bij zichzelf, niet tot de ultieme Aufhebung (Hegel) komen, maar hij volhardt op de plaats van het subject, op het punt van het verschil. Dat punt bevindt zich namelijk buiten de werelden op de plaats waar een identiteit is 'wat ze is', ontsnapt ze aan zichzelf, zodat we met een gedecentreerd subject te maken krijgen:

De wereld is ons dorp geworden, zeggen we, en we denken dat haar identiteit voortaan door alle mensen wordt gedragen en dat de universele mensheid eindelijk subject (drager) van de wereld (en dus van zichzelf) is geworden. Maar reeds in het moment van die bewering zelf heeft dat dorp een 'verschil met zichzelf' gemaakt: precies het standpunt van waaruit we onze bewering doen, positioneert zich buiten die wereld en maakt dat die opnieuw van zichzelf verschilt. Maar uitgerekend dat 'subject', de differentiële 'plaats' tussen de wereld en zichzelf, eigenen wij ons toe als wij de wereld 'ons' dorp noemen. Op die manier verdoezelen we het verschil tussen ons en de wereld en laten het daarenboven handig in ons voordeel uitdraaien. (De Kesel 1999:55)

Dit verschil tussen de wereld en zichzelf is dus zoals reeds aangestipt, duidelijk zichtbaar in diegenen die geen eigen plaats kennen, bij voorbeeld miljoenen mensen die vandaag de dag op de vlucht zijn voor de oorlogen in het Nabije en het MiddenOosten. Door hen worden wij het sterkst geattendeerd op onze tekortkoming, op dit verschil met zichzelf. In dit verschil gaapt een leegte (dit is de leegte die Hegel de lege kern van het subject noemt, de plek van waaruit de vrijheid van het subject mogelijk is) en die niet te overstijgen of af te schaffen (aufzuheben) is.

De huidige vluchtelingen wijzen ons op het ware subject van onze internationale gemeenschap. Ze vormen het constitutieve verschil 'dat ons tot wereldgemeenschap

5 Žižeks voornaamste bezigheid is het subject en zijn positie in de moderne filosofie. Hij streeft naar de rehabilitatie van de moderne subjectiviteit en leunt daarbij op het gedachtegoed van Descartes en de grote Duitse idealisten van Kant tot Hegel, gelezen door de lens van Lacan. Als er één filosoof is die hij moest kiezen, dan is dat ongetwijfeld Hegel, herhaalt Žižek keer op keer. 
maakt als zodanig. In die zin wordt onze universele gemeenschap pas inhen met zichzelf geconfronteerd.' (ibid: 56) Žižek illustreert dit soort antagonismen van het subject met nog andere voorbeelden:

Zo werd in voormalig Joegoslavië de universaliteit vertegenwoordigd door de Albanese en Bosnische moslims, waar alle andere volkeren op neerkeken /.../ Het Griekse demos vertegenwoordigde de universaliteit, niet omdat het de meerderheid van de bevolking vertegenwoordigde en ook niet omdat het de laagste positie in de maatschappelijke hiërarchie bekleedde, maar omdat het juist geen eigen plek in deze hierarchië had, maar een ontmoetingsplaats van conflicterende, elkaar opheffende stromingen was, of in hedendaagse terminologie: een plaats van performatieve contradicties. (Žižek 1998:59-60)

Zo zien we hoe in de ogen van Žižek de dimensie van het universalisme tegenovergesteld is aan het globalisme, deze schemert door het symptomatische (ontwrichtte) element dat tot het geheel behoort heen, zonder hier werkelijk deel van te zijn.

Het is duidelijk dat het Žižek om een kritische analyse van het huidige tolerantiediscours gaat. Volgens hem is het niet het object maar het subject dat in dit multicultureel discours problematisch is. De positie van waaruit de multiculturalist zich uit, wordt door hemzelf verkeerd ingeschat en in die positie verschilt hij niet wezenlijk van de positie van waaruit een racist spreekt. De superioriteit van een racist is duidelijk merkbaar, hij laat het verschil toe, zolang dat zich ergens anders bevindt. Zijn positie wordt steeds duidelijker naarmate zijn redevoering intenser wordt, hij spreekt vanuit een uitzonderingspositie, buiten de universele orde die niet dezelfde is als overal elders. Pas van daaruit kan hij allen als gelijken erkennen (Žižek 1998: 15-16, 19-24).

Ook het subject van op multiculturalisme gebaseerd discours heeft dezelfde opzet, met dit verschil dat die niet zichtbaar is zoals bij een racistisch vertoog. De multiculturalist gelooft in de gelijkwaardigheid van alle culturen en neemt de positie in van de gelijkwaardigheid zelf. Hij is van mening dat hij probleemloos in naam van allen kan spreken en het ontgaat hem, dat hij dat onvermijdelijk doet vanuit een positie die juist van allen verschilt, daarom staat hij er, net als de racist, buiten en dus boven. Beiden ontkennen het verschil waardoor onze universele samenleving wordt bepaald. De multiculturalist neutraliseert elk verschil, de racist is verheven boven dit verschil, aldusDe Kesel over Žižeks exposé over de overeenkomsten tussen het racistisch en multiculturalistisch vertoog (De Kessel 1999: 57).

Met andere woorden, het multiculturalisme is een ontkende, omgekeerde, zichzelf in de staart bijtende vorm van racisme, een racisme op afstand [...] Het heeft zogenaamd respect voor de identiteit van de Anderen en beschouwt deze als een besloten 'authentieke' gemeenschap waar tegenover hij, als multiculturalist, een afstand bewaart die mogelijk wordt gemaakt door zijn bevoorrechte universele positie. (Žižek 1998: 49) 
Žižek attendeert erop dat als het multiculturalisme daadwerkelijk in zijn opzet wil slagen, het politiek actief zou moeten zijn en niet langer mee zou moeten doen aan de depolitisering.

\section{De depolitisering oftewel de culturalisatie van de politiek}

Er bestaan niet alleen foute antwoorden maar ook foute vragen, aldus Žižek. In racistische uitbarstingen ziet men in toenemende mate automatisch het probleem van de intolerantie tegenover andere rassen, religies, culturen, seksuele praktijken of verschillendelevensstijlen. Dat is geenszins vanzelfsprekend, beweert Žižek en hij noemt als voorbeeld Martin Luther King, de sleutelfiguur van de Amerikaanse antiracistische strijd, bij wie men het begrip tolerantie niet zo snel tegenkomt (Žižek 2007: 17). Het gaat echter om ongelijkheid, uitbuiting en onrecht. Daarom ligt de oplossing niet in tolerantie, maar in de emancipatorische politieke strijd. Om te zeggen dat de zwarten van de witten meer tolerantie eisen, zou voor Luther belachelijk en vernederend zijn. Wat hij en zijn medestanders vorderden was wettelijke en economische gelijkheid en rechtvaardigheid. Waarop bij Žižek vanzelf de vraag opkomt waarom in het huidige discours racisme als intolerantie wordt gezien.Zijn antwoord ligt in de manier waarop de liberale multiculturele ideologie te werk gaat, namelijk als de culturalisering van de politiek (Žižek 2007: 118-125; Žižek 1998: 19-24). Het is de ideologie van het westers denken waarvan de kracht volgens Žižek juist daarin bestaat dat zij zichzelf als ideologie ontkent. Ze wil liever overeenkomen met de menselijke natuur.Politieke verschillen - voortgekomen uit politieke ongelijkheid of economische uitbuiting zijn dus genaturaliseerd en geneutraliseerd en zijn tot culturele verschillen verworden (Žižek in De Brabander 2014: 132). Zij zijn een gegeven en daarom kunnen ze niet worden overbrugd, ze worden slechts getolereerd. De oorzaak van deze culturalisering is de terugtrekking van en de mislukking van de directe politieke oplossingen zoals de welvaartsstaat of verschillende sociale projecten. Tolerantie is hun post-politieke surrogaat, stelt Žižek (Žižek 2007: 125).

\section{Tolerantie}

Žižek beweert vaak dat tolerantie een gedesoriënteerd en misleidend begrip is, dat wel op het juiste probleem wijst. In het tolerantie discours komt de Ander steeds aan de orde. Hertmans merkt op dat de Ander nog nooit zo alomtegenwoordig is geweest als juist in onze, door het universalisme gevormde wereld en dat we inmiddels allen vertrouwd zijn met de gedachte dat we zelf een vreemde zijn voor onszelf (Hertmans 2002:28). Volgens Žižek wordt ons door de politiek correcte progressieve academici angepraat, dat de intolerantie tegenover de Ander is geworteld in onze intolerantie tegenover de "Vreemdeling in Onszelf", in ons onvermogen om geconfronteerd te worden met datgene wat we hebben verdrongen. Op die manier is de politiekeconomische strijd dus onmerkbaar veranderd in het pseudo-psychoanalytisch 
drama van het subject dat onmogelijk met zijn innerlijke trauma's geconfronteerd kan worden, constateert Žižek (2008).

De Ander wordt wel getolereerd, maar tot op zekere hoogte, zolang hij niet een echte Ander is, maar de steriele Ander van de premoderne ecologische wijsheid en de fascinerende rituelen (Žižek 1998: 52). In die zin trekt de filosoof een Žižekiaanse parallel met het alledaagse leven; op de markt komen we een hele reeks producten tegen die gezuiverd zijn van hun giftige of kwaadaardige stoffen: koffie zonder cafeïne, room zonder vet, bier zonder alcohol enz. Žižek vraagt verder: en virtuele seks als seks zonder seks? Of Collin Powells doctrine van oorlogvoering zonder slachtoffers (aan onze zijde, natuurlijk) als oorlogvoering zonder oorlogvoering? Of de hedendaagse herdefinitie van politiek als een soort partijloos, boven alle partijen verheven bestuur, als politiek zonder politiek? Dit brengt ons bij een hedendaags tolerant multiculturalisme waarin de Ander gezuiverd is van zijn Anderszijn - de cafeïnevrije Andere (Žižek 2004: 231).

Het algemene beeld van de Ander strookt volgens Hertmans vaker niet dan wel met onze particuliere ervaringen - waardoor vele Europeanen in een moreel dilemma terechtkomen in de trant van: ik heb niets tegen migranten, máár... (2002: 29) In dit verband constateert Žižek dat een van de meest essentiële mensenrechten, dat in een versneld tempo in opkomst is, het recht is om niet lastig te worden gevallen, dat is het recht om op veilige afstand te mogen blijven van de anderen (1998: 49 ; 2007: 42). Gezien de gewelddadige protesten in Europa in verband met de migrantenproblematiek en de reacties erop vraagt Žižek zich af waarom we vandaag de dag te maken hebben met de angst voor de nabijheid van de Ander. Gaat het om het uiteenvallen van de beschermende symbolische muren waardoor de Ander op afstand werd gehouden om niet te dichtbij te komen? De reden hiervoor is te vinden in de botsing van verschillende culturen (2007: 54).

Agressieve reacties zijn vaak het gevolg van het feit dat de Ander als een indringer wordt ervaren, die op een andere manier zijn genot reguleert dan wij (andere sociale praktijken en rituelen). En dat doet hij op de manier die ons stoort, daarom moet hij uit de buurt blijven. Vandaar dat Žižek van mening is dat we 'wederzijds begrip' zouden moeten aanvullen met 'wederzijdse vermijding', met 'het bewaren van de passende afstand, met de nieuwe codex van discretie' (ibid: 55). Hij denkt verder dat afstand houden inherent is aan de Europese sociale structuur dus is het normaal, dat de Ander wordt geïgnoreerd, ook al wonen we schouder aan schouder met hem. In de interactie met de anderen houd ik me aan zekere externe regels zonder met hen de innerlijke wereld te delen 'en misschien is de les van dit alles dat een dosis van vervreemding soms onontbeerlijk is voor een vredige co-existentie van verschillende leefwijzen. Vervreemding is soms geen probleem maar een oplossing.' (ibidem)

Hier treedt de bovengenoemde paradox op dat het met de Ander allemaal goed en wel is, als hij niet te indringerig wordt of met andere woorden, zolang hij niet een echte Ander is. De tolerantie krijgt hiermee een nieuwe invulling. De tolerantie tegenover de Ander betekent dat ik niet te dichtbij de Ander mag komen en zijn ruimte binnendringen - ik houd mezelf op een afstand. 
In die zin verdedigt ook Hertmans een soort distantie als hij inbrengt dat een cultuur recht heeft op haar eigen wereld, 'zelfs, en misschien vooral, op haar eigen regionalisme (2002: 37). Er is in zijn ogen ook geen noodzaak om zichzelf voortdurend te relativeren in een universele, internationale context, ze hoeft zich niet voortdurend te spiegelen aan het 'andere' want dat kan alleen 'ontwrichtend en uiteindelijk banaal zijn'.Dit zou goed functioneren zolang ze niet in de internationale arena mee wil tellen. Koestert ze die internationale ambities wel, dan zou ze tot onze neuroses met betrekking tot het 'andere' veroordeeld zijn, aldus Hertmans.

\section{Egaliseringstendens in de kunst}

Vandaag de dag, nu de crisis op alle gebieden van de menselijke samenleving zich aan het verdiepen is, ontstaan er talloze culturele en politieke en sociale vormen van engagement waarin de samenleving op zoek gaat naar oplossingen voorbij de neoliberale orde. Het is meer dan ooit nodig om het begrip engagement aan een kritische beschouwing te onderwerpen, niet alleen in de politiek maar ook in de kunst, aangezien de kunst zich sinds 1989 ook in Midden- en Oost-Europa hand in hand met de processen van de globalisering ontwikkelde, waarmee het neoliberale kapitalisme zich verder verspreidde.

Daar wijdt Stefan Hertmans zijn essay aan met de titel Esthetica als serviceclub. Over engagement in de kunsten ${ }^{6}$. Volgens de auteur zou door de massale uitbreiding van het begrip engagement in de kunst, een echt engagement volstrekt ondoordacht of met de woorden van Žižek een lege betekenaar zijn geworden. Hertmans neemt progressieve weldenkenden op de hak die ten prooi zijn gevallen aan dogmatische opvattingen over kunsten, die vooral toegankelijk en licht verteerbaar zouden moeten zijn.De heersende tendens is, dat de kunst bevrijd zou moeten worden van elitarisme en intellectualisme want het reflexieve aspect van de kunst is uit den boze. Achter deze afkeer schuilt de behoefte om de kunst te domineren en te controleren. Er zou aangaande de kunst een consensus zijn ontstaan, 'een eigenaardig soort consensus in het populistische middenveld, waarbij conservatief en progressief het over één ding roerend eens lijken te zijn, zonder dat ze dat zelf in de gaten hebben: hun eis voor een entertainende, makkelijk consumeerbare kunst' (Hertmans: 2011). Dat maakt noodzakelijke antagonismen en dynamiek van een levendige en kritische kunst onmogelijk, daarom kan daaruit ongetwijfeld niets werkelijk nieuws ontstaan, stelt Hertmans. Deze consensus komt nu makkelijk overeen met de verwachtingen van een globalistische, kapitalistische, rechtse markt. Dat is volgens hem de ironie van de machtsverhouding in de culturele wereld: dat rechts juist gemobiliseerd is en dat wat er aan de andere kant echt progressief, vernieuwend en kritisch is, niet bij machte is zich hoorbaar te maken. Je zou een soort parallel kunnen trekken met Žižeks constatering die voor de globale politieke arena geldt: een algehele consensus of de depolitisering van de economie brengt een inactief links met zich mee zonder

6 Verschenen in: Mobilisatie van Arcadia (2011), Amsterdam: De Bezige Bij. 
alternatieven, waardoor (populistisch) rechts 'de enige serieuze politieke factor [is] die nog vraagtekens bij de onbeteugelde heerschappij van de markt plaatst' (Žižek 1998: 8). Als je het er niet mee eens bent, als je niet participeert, word je buitengesloten.Er ontstaat een intolerante houding tegenover de kunst die zich in Hertmans' termen niet laat mobiliseren en daarom als snobistisch, elitair, onbegrijpelijk of wat dan ook wordt afgewezen. Hertmans bekrachtigt het dictaat van participatie voor iedereen met de theoretische bevindingen van Žižek en de Belgische politicologe Chantal Mouffe:'Oook Slavoj Žižek en andere postmarxisten bekritiseren steeds nadrukkelijker het inherente geweld van een humanistische cultuuridee die gebaseerd is op een sympathiek ogende insluiting.' (Hertmans: 2011)

\section{Besluit}

Zoals uit voorgaande blijkt, kunnen we Hertmans' en Žižeks vertoog op het gebied van universalisme (paulinisme), multiculturalisme, tolerantie en participatie (engagement) onder dezelfde noemer scharen, hoewel ze deze thema's uit een verschillende invalshoek benaderen. Ze zijn het beiden erover eens dat de problematiek van het multiculturalisme, dat tolerantie, cultuurverschillen en diversiteit op allerlei gebieden veronderstelt, in feite juist zijn tegenpool representeert. Beiden hebben het op dit punt over de egaliseringstendens of homogenisering van de wereld door de alomtegenwoordigheid van het kapitalisme als het universele wereldsysteem.

Žižek is ervan overtuigd dat we Europa meer dan ooit nodig hebben, met zijn erfenis van de Verlichting en het humanisme en al die vrijheden die daarvan het gevolg zijn. Het is niet genoeg om elkaar te tolereren. En tegelijkertijd de juiste distantie te bewaren. In Hegeliaanse termen gesproken: we moeten in staat zijn om het particuliere (particuliere culturele achtergrond, zoals sociale, religieuze of etnische positie) te overstijgen, niet op te geven, om tot het universele te komen. Mensen horen tot een bepaalde groep of groepen en tegelijk hebben ze ook een universele dimensie. In de loop van het leven blijf ik niet dezelfde, maar ik blijf mezelf. Onze identiteit bestaat uit meerdere identiteiten die achter elkaar of naast elkaar kunnen bestaan. Volgens Žižek zit precies dezelfde idee in de emancipatorische kern van de christelijke leer: verlaat je vader en je moeder en volg mij, zegt Christus. Met andere woorden: verlaat je gemeenschap om het universalisme van de mensheid te vinden. Deze emancipatie is een krachtige, gewelddadige daad. Zonder geweld, die niet fysiek hoeft te zijn, kun je je niet onttrekken aan je wortels, kun je niet de universele vrijheid ervaren, wat uiteindelijk een immens bevrijdende ervaring is, aldus Žižek (2015).

\footnotetext{
7 In de negentiger jaren waren Chantall Mouffe, de Argentijnse cultuurtheoreticus Ernesto Laclau en Slavoj Žižek intellectuele soulmates. Mouffes en Laclaus werk Hegemony and Socialst Strategy: Towards a Radical Democratic Politics (1985) heeft en beslissende rol gespeeld in de ontwikkeling van Žižek.
} 


\section{Literatuuropgave}

Brabander, R. de 2014. Wie wil er nou niet zelfredzaam zijn? De mythe van zelfredzaamheid. Antwerpen/Apeldoorn: Garant.

Caputo, D. J. 2009. 'Postcards from Paul: Subtraction versus Grafting'. In: J. D. Caputo \& L. M. Alcoff (red.), St. Paul among the Philosophers. Bloomington/Indianapolis: Indiana University Press, pp. 1-26.

Henwood, D. 2002. 'I am a Fighting Atheist: Interview with Slavoj Zizek'. Left Business Observer, 59. Geraadpleegd op 9 juni 2016 van http://bad.eserver.org/ issues/2002/59/zizek.html

Hertmans, S. 1995. 'Iedereen danst op de rand van zijn symptoom. Slavoj Žižek over Hitchcock en Bosnië. S. Hertmans Fuga's en pimpelmezen. Over actualiteit, kunst en kritiek. Amsterdam: Meulenhoff/Kritak, pp. 75-94.

Hertmans, S. 2002. Het putje van Milete. Amsterdam: Meulenhoff.

Hertmans, S. 2011. De mobilisatie van Arcadia. Amsterdam: De Bezige Bij. [E-boek]

Kesel, M. De 1999. 'Tweemaal voorbij Hegel. Over William Desmond, Het tragische en het komische en Slavoj Žižek, Pleidooi voor intolerantie.. De Uil van Minerva, 16, pp. 47-64.

Leick, R. Von. 2015. 'Unsere Trägheit ist die größte Gefahr' (Gespräch mit Slavoj Žižek). Der Spiegel (14 maart 2015).

Žižek, S. 1998. Pleidooi voor intolerantie. Amsterdam: Boom.

Žižek, S. 2004. 'Welcome to the Desert of the Real'. A. Easthop \& K. McGowan (red.), $A$ Critical and Cultural Theory. Reader. ( $2^{\mathrm{e}}$ editie). Toronto/Buffalo: University of Toronto Press, pp. 231-234.

Žižek, S. 2006. The Parallax View. Cambridge/Massachusetts/London: The MIT Press.

Žižek, S. 2007. Nasilje. Ljubljana: Društvo za teoretsko psihoanalizo.

Žižek, S. 2007a. 'Multiculturalism, Pluralism and Tolerance'. J. Baggini \& J. Stangrooms (red.), What More Philosophers Think [E-boek]. London/New York: Continuum.

Žižek, S. 2008.'The Prospects of Radical Politics Today’. International Journal of Baudrillard Studies 5/1. Geraadpleegd op 10 juni 2016 van http://www2.ubishops. ca/baudrillardstudies/vol5_1/v5-1-article3-zizek.html.

Žižek, S. 2009. 'From Job to Christ: A Paulinian Reading of Chesterton'. J. D. Caputo \& L. M. Alcoff (red.), St. Paul among the Philosophers Bloomington/Indianapolis: Indiana University Press, pp. 39-60. 